\title{
A valorização das plantas medicinais como alternativa à saúde: um estudo etnobotânico
}

O Estado Santa Catarina é dotado de reconhecida biodiversidade, grande variedade de paisagens naturais: mata atlântica, litoral e cadeias de montanhas e de serras, sendo que Águas Mornas é classificada como área de imigração colonial de europeus (sec. XIX). Além disso, trata-se de uma região de rica diversidade cultural, composta por migrantes de outras regiões do Brasil, resultando em miscigenação cultural, o que atua decisivamente na utilização das plantas medicinais. Para entender o uso desses recursos naturais, suas relações existentes entre o homem e o ambiente, realizou-se um estudo etnoecológico versando os usos das plantas medicinais na medicina popular no Bairro de Santa Isabel, no Município de Águas Mornas/SC. De fato não se tem registro de nenhum levantamento de plantas medicinais entre a população do munícipio, sobre plantas medicinais, o que resulta na problemática da pesquisa; ou seja, em que nível a falta de valorização dos conhecimentos sobre plantas medicinais pode afetar a saúde da população local, que procura quase que única e exclusivamente os tratamentos da medicina a falta de valorização dos conhecimentos sobre plantas medicinais pode afetar a saúde da população local, que procura quase que única e exclusivamente os tratamentos da medicina convencional, lotando hospitais e unidades de saúde, muitos deles acometidos de moléstias que poderiam ser sanadas por meio do uso de ervas naturais? A coleta dos dados foi realizada
em dois momentos. Primeiramente ocorreu a entrevista com a população, por meio de formulários semiestruturados, estabelecendo um estudo de caso, ou seja, um levantamento dos conhecimentos populares dos envolvidos na pesquisa. No segundo momento foi realizada entrevista com casal raizeiro/benzedor, utilizando também entrevistas semiestruturadas, analisado os seguintes aspectos: tempo de trabalho com plantas medicinais, tempo de residência em Santa Isabel (mínimo 8 anos), além de quais as plantas que usam. A maioria do púbico entrevistado possui entre 15 e 50 anos, caracterizando uma populacão jovem, de baixa renda, com uma renda mensal de 1 a 2 salários mínimos. Não diferente, mesmo que tenha apresentado grande parcela de pessoas jovens, o típico usuário de plantas medicinais é dominante, por mulheres idosas, com pouco ou nenhum estudo. Aprenderam suas receitas com os pais, avós e outros ancestrais. Verificou-se que os recursos naturais nativos têm-se escasseado, levando em consideração o impacto de culturas imigrantes, influenciando significativamente na tradicional cultura de uso de plantas medicinais, com a introdução de hábitos e muitas plantas exóticas.

Palavras-chave: Etnobotânica; Plantas medicinais; Recursos Naturais; Saúde.

\section{Valuing medical plants as an alternative to health: an ethnobotanic study} \begin{abstract}
The state Santa Catarina is endowed with recognized biodiversity, a wide variety of natural landscapes: Atlantic Forest, coastline and mountains and mountain ranges, and Águas Mornas is
classified as an area of colonial immigration of Europeans (sec. XIX). Moreover, it is a region of rich cultural diversity, composed of migrants from other regions of Brazil, resulting in cultural classified as an area of colonial immigration of Europeans (sec. XIX). Moreover, it is a region of rich cultural diversity, composed of migrants from other regions of Brazil, resulting in cultural
miscigenation, which acts decisively in the use of medicinal plants. To understand the use of these natural resources, their existing relations between man and the environment, an miscigenation, which acts decisively in the use of medicinal plants. To understand the use of these natural resources, their existing relations between man and the environment, an
ethnoecological study was carried out, addressing the uses of medicinal plants in folk medicine in the Santa Isabel neighborhood, in the municipality of Águas Mornas/SC. In fact not If there is a record of any survey of medicinal plants among the population of the world, about medicinal plants, which results in the research problem; In other words, at what level the lack of appreciation of knowledge about medicinal plants can affect the health of the local population, which seeks almost exclusively the treatments of conventional medicine, filling up hospitals and health units, many of them Affected by diseases that could be remedied through the use of natural herbs? Data collection was performed in two moments. First, the interview with the population was conducted through semi-structured forms, establishing a case study, that is, a survey of the popular knowledge of those involved in the research. In the second moment, an interview was carried out with a couple of Raizeiro/Benzedor, also using semi-structured interviews, analyzing the following aspects: Working time with medicinal plants, time of residence in ants is dominant, by elderly women, with little or no study. They learned their recipes from parents, grandparents and other ancestors. It was found that native natural resources have been scarce, taking into account the impact of immigrant cultures, significantly influencing the traditional culture of medicinal plant use, with the introduction of habits and many plants Exotic.
\end{abstract}

Keywords: Ethnobotany; Medicinal plants; Natural resources; Health.

Topic: Uso de Recursos Naturais

Reviewed anonymously in the process of blind peer.

Tayronne de Almeida Rodrigues (it)

Faculdade de Juazeiro do Norte, Brasil

http://lattes.cnpq.br/8602100500602426

http://orcid.org/0000-0001-9378-1456

tayronnealmeid@gmail.com

João Leandro Neto (iD)

Faculdade Entre Rios do Piauí, Brasil

http://lattes.cnpq.br/0489242460344918

http://orcid.org/0000-0003-1738-1164

joaoleandro@gmail.com

Tainnã de Almeida Rodrigues Carvalho (i)

Centro Universitário Dr. Leão Sampaio, Brasil

http://lattes.cnpq.br/8106605310169257

http://orcid.org/0000-0001-6712-1438

tainaetiago@hotmail.com

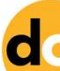

DOI: 10.6008/CBPC2179-6858.2020.001.0037
Received: 09/12/2019

Approved: 15/01/2020

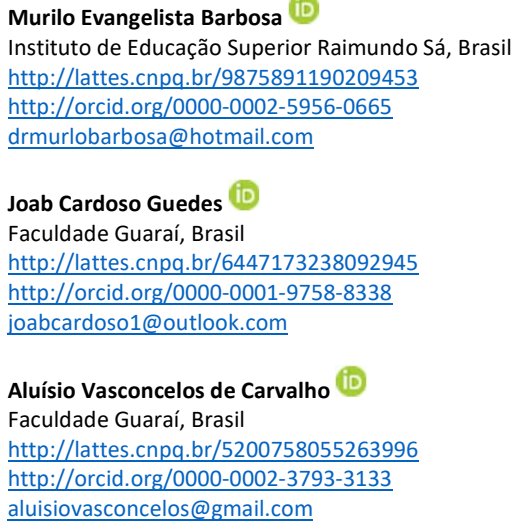

Referencing this:

RODRIGUES, T. A.; LEANDRO NETO, J.; CARVALHO, T. A. R.; BARBOSA M. E.; GUEDES, J. C.; CARVALHO, A. V.. A valorização das plantas medicinais como alternativa à saúde: um estudo etnobotânico. Revista Ibero Americana de Ciências Ambientais, v.11, n.1, p.411428, 2020. DOI: http://doi.org/10.6008/CBPC21796858.2020.001.0037 


\section{INTRODUÇÃO}

Segundo Christo et al. (2010), muito antes de aparecer qualquer forma de escrita o homem já usava as plantas como alimento e como remédio e, ao longo dos séculos, teve as alegrias do sucesso e as dores do fracasso nas suas experiências com ervas, que às vezes curavam, às vezes matavam e outras vezes produziam dores, cólicas ou alucinações fantásticas. Em se tratando da história das ervas, é praticamente impossível separar a fantasia da realidade. As lendas, os mitos, são parte importante da cultura de um povo. Através delas, pode-se aprender sobre seus costumes e tradições.

Os documentos médicos mais antigos que se tem notícia são os dos chineses, que já em 3700 a.C. diziam, em seus tratados de medicina, que para cada doença havia uma planta que seria o seu remédio natural. Segundo Tomazzoni (2014), a primeira farmacopeia teria sido escrita por Shen Nung, um imperador sábio que viveu entre 3700 e 2600 a.C. e que podia observar com facilidade o que acontecia em seus órgãos quando tomava algum de seus preparados de ervas porque tinha o abdômen transparente.

Conforme o autor sugere, ao longo do tempo, seguem-se os egípcios, que deixaram papiros preciosos, um dos mais famosos é datado de 1500 a.C. Nele está registrado que os egípcios usavam ervas aromáticas na medicina, cosmética, culinária e, sobretudo, na sua arte, nunca superada, de embalsamar corpos. Na Mesopotâmia se destacam os sumérios com receitas tão preciosas que eram guardadas somente nas cabeças dos sábios sacerdotes e dos grandes feiticeiros.

No Antigo Testamento, registra-se as ervas bíblicas, encontrados em Abraão, mais ou menos em 1500 a.C., e nessa época as ervas eram usadas somente como alimento e condimento porque os hebreus acreditavam que só Deus podia curar e que era pecado interferir em seus desígnios. A única planta considerada medicinal era a raiz da mandrágora, usada como analgésico para aliviar grandes sofrimentos.

Aos poucos, isso foi mudando e os últimos profetas do Antigo Testamento já ensinavam que Deus concedia a certas pessoas piedosas, através da oração, o conhecimento das ervas para curar doenças. No período do ano 1000 a.C. se encontra o apogeu das ervas medicinais e mágicas. O principal objetivo da medicina hindu era prolongar a vida, e a principal fonte de conhecimento era as ervas, consideradas filhas dos deuses. Só podiam ser colhidas por pessoas puras e piedosas e deviam crescer longe da vista humana e do pecado. Eram usadas basicamente para limpar o corpo, estimular as secreções e ação sedativa (CHRISTO et al., 2010).

O Brasil possui uma grande diversidade de espécies vegetais, inúmeras utilizadas como medicinais perfaz uma grande riqueza florística e isso provém dos seus ecossistemas, restritos a três grandes formações: o cerrado, o pantanal, a floresta amazônica, a mata atlântica, entre outros biomas que contribuem com espécies vegetais distintas e que, por vezes, se inter-relacionam caracterizando fisionomicamente nossa flora.

Segundo Torres (2009), a planta é muito mais o núcleo pedagógico da educação popular para a saúde que uma mera alternativa mais barata e mais natural no tratamento das doenças da Atenção Primária a Saúde (APS). Nesse sentido, faz-se imprescindível que seja realizado novos estudos etnobotânicos sobre 
plantas medicinais utilizadas por raizeiros, com objetivo recuperar os conhecimentos tradicionais, viabilizando o acesso da comunidade às informações mais sistematizadas a respeito de plantas medicinais. Assim como em outras regiões, as práticas agrícolas ocidentais, fundadas na monocultura e voltadas para atender o mercado consumidor, vêm devastando e muito as áreas próximas às cidades, isso contribui na redução da biodiversidade dessas áreas.

A escolha das plantas como forma de alimento, construção de materiais como ferramentas de trabalho, como ornamentais e outros fins refletem os diferentes usos nas diferentes áreas. Sendo assim os dados levantados são importantíssimos para relação de sua disponibilidade, manutenção e avaliação para as interações sociais, ambientais e econômicas, uma vez que o ambiente natural pode afetar as condições sociais direta ou indiretamente modificando as experiências humanas. Nessa direção, o presente trabalho visa a conhecer a tradição do uso de plantas medicinais junto da população da comunidade Santa Isabel Águas Mornas/SC, registrando e catalogando as plantas medicinais que a população utiliza para curar seus males.

\section{REVISÃO TEÓRICA}

\section{A Relevância no Uso das Plantas Medicinais: Aportes Históricos}

A importância na administração das plantas medicinais perpassa através dos tempos e pode ser medida no empenho da Europa em achar um 'caminho marítimo para as índias' a fim de conseguir temperos e especiarias. O grande historiador grego Xenofonte descreve os jardins paradisíacos e cheios de ervas dos reis persas Dario e Ciro e, quando Alexandre, o Grande, conquistou a Pérsia, levou para o mundo helênico a moda dos maravilhosos jardins cheios de flores, ervas aromáticas e fontes (SILVA et al., 2011).

Na Grécia de 460 a.C Hipócrates, considerado até hoje o 'Pai da Medicina', descreve seus princípios éticos, que ainda servem de juramento para os novos médicos, e ele achava, como na homeopatia moderna, que se devia tratar a doença e não o doente. A dieta, os hábitos de higiene do corpo e da mente eram sempre baseados em ervas e em princípios filosóficos. Seus conhecimentos atravessaram os séculos e continuam estimulando novas pesquisas. Foi na época de Hipócrates que apareceu de novo a Doutrina das Assinaturas, já pesquisada pelos chineses, que acreditavam haver uma ligação entre a forma e a cor das plantas e a doença a ser tratada.

Um dos maiores jardins gregos foi o de Teofrasto, considerado o 'Pai da Botânica'. Discípulo de Aristóteles e de Platão escreveu uma História das plantas onde descreve 450 tipos diferentes de árvores, flores e ervas. Com o apogeu do Império Romano o saber se deslocou para Roma, com os dois maiores herbalistas do começo da era cristã; Dioscórides e Galeno. O primeiro foi médico de Nero e, com ele junto de seus soldados legionários, perambulou por todo o mundo mediterrâneo colecionando centenas de plantas. Mais tarde escreveu o catálogo de medicina herbalista chamado 'Matéria Médica' que apareceu em 78 d.C. (OLIVEIRA et al., 2012).

Essa obra serviu de base para todos os conhecimentos médicos do Oriente, entrou no Ocidente pela 
porta da Espanha e se espalhou pela Europa, tomando-se a principal fonte de informação médica por centenas de anos. A cópia mais antiga dos escritos de Dioscórides é um manuscrito bizantino do século VI chamado Códice Vindobonesis, considerado o documento médico mais importante até o aparecimento da obra de Leonardo Fuchs chamada História stirpium, que data de 1542.No século XI apareceu Galeno, também grego e médico do imperador Marco Aurélio, este descobriu um método de separar os princípios ativos das plantas, denominado galênico, que é usado até hoje (OLIVEIRA et al., 2012).

Consoante Tomazzoni (2006), com o declínio do Império Romano e a desestruturação das sociedades ocidentais por causa das invasões bárbaras, a importância da medicina voltou-se outra vez para o Oriente e foi absorvida especialmente pelos árabes, que tiveram em Avicena (980 - 1037 d.C.) seu médico maior. Usava lavanda, camomila e menta em muitos de seus preparados e ficou conhecido por mais de seis séculos como o 'Príncipe dos Médicos'. As primeiras farmácias de Bagdá datam desta época.

Na idade Média os mosteiros se tornaram centros importantes de estudo, e os livros existentes foram todos recolhidos pelos monges, que se apoderaram do saber antigo. Ao redor dos conventos, igrejas e mosteiros foram cultivados maravilhosos jardins de ervas que eram usados como alimento, bebidas e medicamentos. Especialmente hoje, quando muitos dos jardins antigos estão sendo recuperados, pode-se visitar na Europa, principalmente na Inglaterra, catedrais, mosteiros, palácios e universidades com preciosas coleções de ervas.

No século $X$ foi criada em Salemo, na Itália, uma universidade que reunia todos os ensinamentos da Antiguidade e do mundo árabe. Esta escola tomou-se centro de estudos importantíssimo e um modelo para todas as outras universidades que se multiplicaram pela Europa a partir desta época. Sua obra mais importante é o Regimen sanitatis salenitatum, que trata das ervas medicinais (ANTÔNIO et al., 2014). 0 referido autor relata que, três séculos depois as viagens de Marco Pólo aos confins da terra, tornou-se ainda mais importante o uso das ervas e das especiarias, que eram então mercadorias de valor incalculável. Com a invenção da imprensa em 1450 e as descobertas do caminho marítimo para as Índias e das Américas, começou um novo ciclo, pois estes acontecimentos mudaram a face da Terra.

No século XVI, surgiu na cena médica europeia um suíço chamado Philippus Aureolus Théophrastus, conhecido mais tarde como Paracelso. Viajou por toda a Europa à procura de plantas e minerais, mas principalmente ouvindo feiticeiros, curandeiros e parteiras. Oliveira et al. (2012) descrevem o grande escândalo das pessoas cultas em saber que Paracelso, não escrevia suas observações em latim, mas em linguagem comum, e tinha ainda a audácia de comparar o conhecimento cientifico da época com o dos curandeiros e parteiras. É reconhecido como um grande alquimista e sem dúvida mudou o curso da medicina ocidental com suas descobertas e estudos que serviram de base para os pesquisadores dos séculos XIX e XX.

No reinado de Elizabeth I da Inglaterra (1558 - 1603), tempo famoso de pirataria, a importância das ervas, dos condimentos e das especiarias era tão grande quanto a do ouro e da prata, e nem se pode imaginar as tragédias acontecidas por causa de um quilo de canela ou de pimenta. Diz-se que a mesma Inglaterra, cheia de rainhas, príncipes e piratas, era também a Inglaterra das bruxas, fadas e duendes e o saber das ervas pertencia a esses seres sobrenaturais que habitavam os pântanos e as florestas. Mesmo assim, rara era a 
dona-de- asa do século XVI que não tinha em sua sala de jantar um armário cheio de plantas para as doenças do dia-a-dia.

Segundo Gomes et al. (2017), os primeiros registros das ervas americanas foram feitos no ano de 1552 por um médico mexicano chamado Juan Badianus. Outro importante herbalista americano foi o espanhol Monardes, que escreveu sobre as ervas do Novo Mundo. Neste mesmo século o herbalista mais conceituado era Gerard, e seu famoso livro The herbal, publicado pela primeira vez em 1597, ainda pode ser encontrado nas livrarias inglesas.

Cabe lembrar que os primeiros imigrantes trouxeram para as Américas as sementes de suas ervas preferidas, como o confrei e a camomila (Symphytum officinale L., Matricaria chamomilla L.), respectivamente, que logo floresceram com as plantas nativas, da quais a mais usada pelos índios americanos era bergamota que, em homenagem a Monards, chamou-se Monarda didyma L., sendo muito usada até hoje (ANTÔNIO et al., 2014).

O interesse pelas ervas cresceu até a época da Revolução Americana e se estendeu até a República. Thomas Jefferson plantava pessoalmente as suas ervas preferidas, entre elas a menta (Mentha arvensis L.), e sobretudo o Tropaeolum majus, conhecido como Capuchinha, Agrião-do-México, Capuchinha-de-floresgrandes, Chagas-de-Cristo. Mas foi com os shakers, grupo religioso que baseava sua vida na simplicidade, que as ervas tiveram seu apogeu na América e, com eles, sua importância econômica durou mais de cem anos (GOMES et al., 2017).

Ainda no século XVIII, Lineu, o grande naturalista sueco, criou a nomenclatura e a sinonímia botânica, dividindo as plantas em 24 classes, o que permitiu um estudo mais completo e abrangente. No final do século XIX, com a Revolução Industrial e o avanço dos conhecimentos no campo da química, tomou-se ridículo acreditar no poder curativo das ervas, mas hoje, depois de tantos avanços e desilusões na obtenção de remédios químicos, o mundo inteiro está empenhado em redescobrir os verdadeiros valores da vida através das plantas (ANTONIO et al., 2014).

Como explica o referido autor, entre os mais famosos herbalistas modernos, podemos citar Maurice Messegué, francês de Gers, região Sul da França. Com a consciência de um estudioso moderno, Messegué está sempre alertando para os perigos da poluição e da destruição da natureza. E com a simplicidade característica de um sábio de todas as épocas, ensina que na 'farmácia do bom Deus' é encontrado tudo o que é necessário para uma vida pura e sã. Aqui no Brasil começou a trilhar este caminho, que alia o bom senso à ciência e ao folclore. Historicamente, quando os portugueses aqui chegaram, no começo do século $\mathrm{XVI}$, encontraram índios que usavam Tuncum (Bixa orellana L.), para pintar e proteger o corpo das picadas dos insetos e tingir os objetos feitos de barro.

Estudar as ervas deveria ser estudar o Brasil em sua dimensão continental e seu clima, que vai do tropical até o temperado. Desde a famosa carta de Caminha sabe-se que o Brasil é chamado o país fértil, e mais que isto, a grande quantidade de plantas nativas que nascem espontaneamente do Amazonas até o Rio Grande do Sul poderia servir de base para alimentação, medicamentos, cosméticos e temperos de toda a população e ainda ser exportada. Nesse sentido, questiona-se onde está guardada a ciência dos índios, tão 
desprezada pelos colonizadores portugueses?. O padre José de Anchieta bem que tentou explicar o uso e a importância dos nossos vegetais nas 'Cartas' que escreveu a seus superiores jesuítas, mas popular mesmo só ficou o pau - Brasil.

Lima et al. (2012) dizem que os primeiros a terem usado a medicina herbalista com algum critério teriam sido então os paulistas, em suas 'Entradas e Bandeiras', usando os conhecimentos trazidos das índias Orientais por viajantes. Mais tarde, os negros escravos começaram a procurar em nossas matas algumas plantas que substituíssem a sua culinária e medicinas nativas. Na Bahia, são encontrados alguns estudos que são preciosíssimos, mas continuam sendo procurados mais como curiosidades que propriamente como ciência antiga. O Brasil é até hoje, apesar dos desmatamentos, um verdadeiro 'celeiro verde'.

Espera-se chegar ao fim deste ciclo e que se recomece a perceber a importância da vida natural e saudável. A atenção dada às ervas, talvez seja o início de uma nova era que está chegando cheio de amor e calor humano. Como se observou, ao longo dos tempos, as plantas têm tido importante papel em relação ao desenvolvimento das civilizações, com referência à alimentação, curas, vestuários, moradia, transporte e responsáveis pela vida aeróbica.

Com o desenvolvimento da sociedade e o aumento do conhecimento humano, partiu-se para a industrialização de vários produtos vegetais e muitos princípios ativos como forma de curas. O conhecimento popular, contudo, se mantém até os dias atuais para o benefício das populações. No que diz respeito a plantas medicinais esses saberes antecedem a Química, a Farmacologia, unindo essas áreas para um melhor entendimento do saber medicinal, isso remonta a era Paleolítica (LINHARES et al., 2014).

Pode-se considerar então como Etnobotânica o estudo multidisciplinar, combinando ciências naturais e humanas que deve envolver cultura, geografia, sensoriamento remoto, biologia, recursos naturais, saúde pública e economia. O ramo da ciência que estuda essas interações entre ciência-homem-natureza é chamado de etnobiologia que se trata do estudo do conhecimento e das conceituações desenvolvidas por quaisquer sociedades a respeito da biologia, ou seja, o estudo do papel da natureza no sistema de crenças e de adaptação do homem a determinados ambientes (NETO et al., 2014).

Neste sentido, a etnobiologia relaciona-se com a ecologia humana, mas enfatiza as categorias e conceitos cognitivos utilizados pelos povos em estudo. Tratando da etnobotânica, pode-se dizer que é 'a relação entre o homem e as plantas no decorrer do tempo e em diferentes ambientes'; acrescentando ainda que dois fatores determinantes para essa relação são o ambiente e a cultura, diante de um campo cientifico da etnobotânica deveria abordar entre outros aspectos, a forma como o homem acumula e transmite o conhecimento sobre o ambiente, a geração de tecnologias para utilizar os recursos naturais (seleção e domesticação de espécies vegetais, produção de medicamentos) e o impacto desta mesma tecnologia sobre a relação homem - planta (NETO et al., 2014).

Nesse sentido, percebe-se que o ambiente e a cultura são considerados os fatores determinantes nos estudos em etnobiologia, pois estabelecem relações entre o homem e as plantas através dos tempos e em diferentes ambientes. Assim a etnobiologia pode ser considerada a força capaz de prover uma linha teórica para integração dos diferentes subsetores das ciências tanto sociais, naturais quanto de outros 
sistemas científicos, sendo que do ponto de vista filosófico, é o princípio gerador ao servir de mediador entre as tantas diferenças culturais; buscando, assim, a compreensão e o respeito entre os povos, sobre os conhecimentos e conceituações desenvolvidas pelas diversas sociedades tradicionais em relação à biologia.

Conforme Oliveira et al. (2016), o conhecimento e o uso de práticas adequadas têm contribuído muito para o desenvolvimento de novos desafios de planejamento e políticas de mercado, que conceba soluções para os problemas locais e regionais de saúde pública. O referido autor diz que ocorre a busca da identificação dos efeitos da política pública em recursos destinados ao conhecimento das relações entre plantas e a diversidade de seus usos.

Uma vez com preços exorbitantes de remédios a população mais carente tem como saída ou endividamento nas farmácias, ou a obtenção de plantas medicinais através de pessoas que comercializam as mesmas ou o cultivo dessas plantas em seus quintais, a solução mais simples seria a população ter as plantas em casa, na escola ou na comunidade, nossa própria farmácia verde, recomendando-se sempre as ervas básicas, seu cultivo e sua manipulação.

Ribeiro (2015) elucida que existem no Brasil, três tipos de influências na formação da medicina popular: a colonização portuguesa; a dos indígenas que usam a fitoterapia dentro de uma visão mística, onde o pajé da tribo utiliza as plantas entorpecentes para sonhar com o espírito que lhe revelaria a planta para cura do enfermo e dos negros trazidos da África como escravos, com uma medicina, mágica, caracterizada pela prática da expulsão do demônio.

Cabe ressaltar a importância de projetos de hortas medicinais padronizadas em comunidades organizadas, dando uma característica ao programa de medicina social, usando as plantas medicinais para o combate de muitos males, orientando devidamente o emprego de plantas medicinais, nos programas de atenção primária de saúde e do êxito do programa de pesquisa sobre plantas medicinais, oferecendo assistência farmacêutica fitoterápica de base científica, sem nenhum fim lucrativo.

As investigações científicas com plantas medicinais envolvem inúmeros elementos, sendo um deles o próprio caráter inter e multidisciplinar que, se por um lado, representa problemas, obstáculos e cuidados, por outro, permite aos pesquisadores obterem conhecimentos mais amplos e ricos que aqueles obtidos em linhas específicas de pesquisa.

Conforme Santos (2004), estes elementos permeiam desde a cultura popular a medicina folclórica e todos os seus componentes, passando pelo misticismo de inúmeras seitas e práticas de saúde que se utiliza de plantas medicinais até o prazer e o desafio de estudar detalhadamente uma espécie vegetal, determinando de modo exato e racional a estrutura de uma nova molécula com potencialidades de se transformar em um medicamento disponível e aprovado. A cada dia, torna-se necessária a busca pelo natural, a volta da sabedoria popular, comparando-a com os conhecimentos científicos, que nos possibilitam conhecer os princípios ativos e a toxidade das ervas, bem como, os cuidados que devesse ter na utilização dos mesmos. 


\section{METODOLOGIA}

A presente pesquisa foi desenvolvida no Bairro de Santa Isabel, Município de Águas Mornas/SC), é localizado a 48 quilômetros da Capital do Estado, Florianópolis. Situada a 59 metros de altitude, Águas Mornas tem as seguintes coordenadas geográficas: Latitude: $27^{\circ} 41^{\prime} 44^{\prime \prime}$ Sul, Longitude: $48^{\circ} 49^{\prime} 24^{\prime \prime}$ Oeste (figura 1).

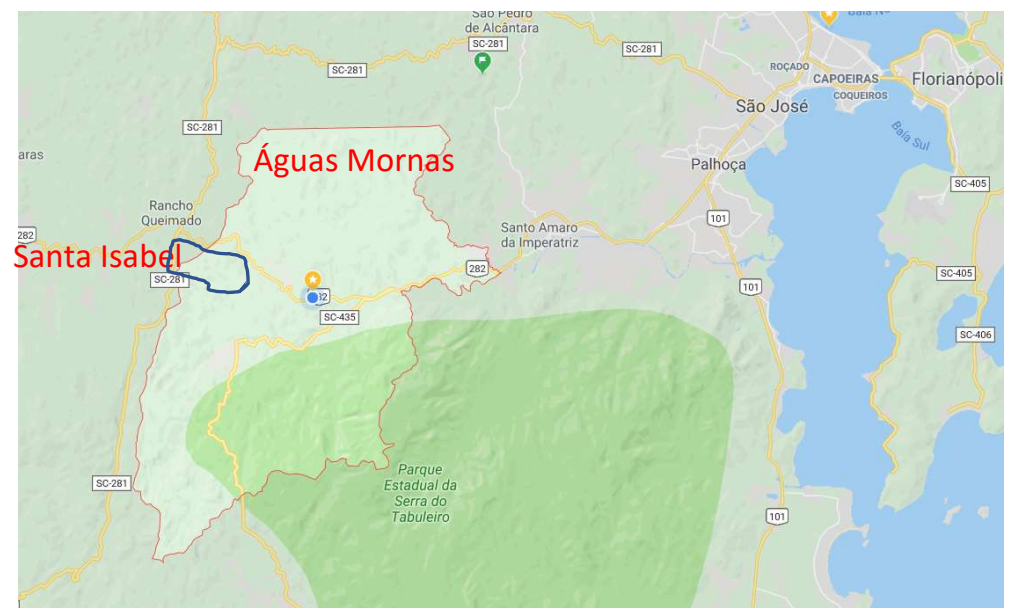

Figura 1: Localização Espacial de Santa Isabel, Águas Mornas/SC. Fonte: Google Inc. (2019).

A coleta dos dados do presente trabalho foi realizada em dois momentos: Primeiramente ocorreu a entrevista com a população, onde foram utilizadas entrevistas contendo perguntas semiestruturadas com a comunidade do bairro de Santa Isabel baseado na metodologia de Marconi et al. (2008). Com a população, foram levantados os seguintes aspectos: quantidade de pessoas na família, sexo, idade, nível socioeconômico, se usam plantas consideradas medicinais, com quem e como aprendeu a fazer uso das plantas onde buscam essas plantas (se elas estão cultivadas no quintal ou se buscam em algum outro local), como é usada a planta (indicações de uso), qual a parte da planta que é utilizada, qual a eficácia das plantas utilizadas.

Durante a pesquisa de campo, percebeu-se a importância do uso de estratégias que garantissem a maior precisão das investigações. Seguindo a orientação metodológica de White (1977), utilizou-se técnicas baseadas estrategicamente em ouvir, perguntar e observar. Como ponto de partida, adotou-se o procedimento ouvir, em que os interlocutores pudessem se expressar livremente, revelando as suas percepções sem a influência dos pesquisadores, de forma a compreender os participantes do levantamento perceptivo (WHITE, 1977). A unidade amostral deste trabalho é caracterizada por 56 pessoas representando a população do bairro de Santa Isabel, escolhida de forma aleatória, utilizando como critério de inclusão o uso de plantas medicinais.

\section{RESULTADOS E DISCUSSÃO}

\section{Perfil dos Entrevistados}

Na Tabela 1, apresentada abaixo, está registrada a origem dos 56 entrevistados, onde o principal estado de origem é São Paulo com 21 pessoas (37,50\%), o Estado de Mato Grosso com 17 pessoas (30,35\%), 
Minas Gerais 5 pessoas (8,92\%), Mato Grosso do Sul 5 pessoas (8,92\%), Paraná 2 pessoas (3,57\%), Alagoas2 pessoas (3,57\%). Os Estados da Bahia, Espírito Santo, Pernambuco, Rio Grande do Norte, Goiás foram citados com 1 morador cada, juntos perfazendo (8,92\%) do universo entrevistado.

Tabela 1: Origem da população: Estado.

\begin{tabular}{|l|l|l|}
\hline Estado & Núm. de informantes & Porcentagem \\
\hline São Paulo & 21 & $37,50 \%$ \\
\hline Mato Grosso & 17 & $30,35 \%$ \\
\hline Minas Gerais & 5 & $8,92 \%$ \\
\hline Mato Grosso do Sul & 5 & $8,92 \%$ \\
\hline Paraná & 2 & $3,57 \%$ \\
\hline Alagoas & 2 & $3,57 \%$ \\
\hline Bahia & 1 & $1,78 \%$ \\
\hline Espírito Santo & 1 & $1,78 \%$ \\
\hline Pernambuco & 1 & $1,78 \%$ \\
\hline Rio Grande do Norte & 1 & $1,78 \%$ \\
\hline Goiás & 1 & $1,78 \%$ \\
\hline
\end{tabular}

Zeni et al. (2017) também registra essa diversidade cultural trazida pelos migrantes em seu Estudo na Cidade de Blumenau/SC, ressaltando que mesmo com a evidente introdução de elementos culturais e florísticos de origem de outros estados, observa-se que ocorre o domínio da cultura local em relação às plantas medicinais. Com os muitos anos de moradia no município a população adquiriu um certo domínio em relação ao conhecimento de plantas nativas.

Quanto à faixa etária dos entrevistados na presente pesquisa, o maior número de entrevistados possui entre 15 e 50 anos, caracterizando uma população jovem, embora o número de pessoas com idades superiores aos 50 anos apresentam um número significativo na amostra. Representam assim na faixa dos 15 aos 50 um percentual de 69,64\% com 39 pessoas e a faixa de 50 a 80 anos, perfaz 30,35\% no universo da pesquisa.

Diante da questão do estudo da renda familiar dos entrevistados, constatou-se que a população do bairro é caracterizada como de baixa renda, sendo em sua maioria com uma renda mensal de 1 a 2 salários mínimos, sendo que 10,71\% não sabem dizer a renda da família. Cabe ressaltar que 85,71\% responderam e $14,28 \%$ não optaram em não responder.

Quanto ao gênero, 17,85\% dos entrevistados são homens e $82,14 \%$ mulheres. Nota-se que ocorre a predominância de mulheres, isso se explica pelo fato dos horários das entrevistas serem pela manhã e meio da tarde, embora isso tenha ocorrido não se pode descartar a participação dos homens, que mesmo em número menor, se mostraram muito bem informados a respeito do assunto de plantas medicinais nos diversos aspectos perguntados.

Muitos homens acham que isso é coisa de mulher e muitas das vezes chamavam as mulheres para responderem a entrevista. Dos entrevistados, a maioria (58,92\%) é representada por pessoas que não possuem o ensino fundamental completo. Em segundo lugar, temos um percentual de 19,64\% de pessoas que não frequentaram a escola. Contudo, pode-se afirmar que apresenta um total de $3,57 \%$ de pessoas que estão cursando o ensino superior.

Comparando idade, nível de escolaridade e renda familiar, tem-se um público com características 
heterogêneas. É perceptível mesmo com o número de pessoas jovens que conhecem ou fazem uso de plantas medicinais prevalecem às características de um típico usuário de plantas medicinais, mulheres idosas, sem escolarização, com renda mensal de origem da aposentadoria ou não sabem sua renda, que aprenderam suas receitas com os pais, avós, ou outros ancestrais.

Zeni et al. (2017) menciona que mulheres geralmente idosas usam bem mais a plantas medicinais que os homens e pessoas jovens. A autora também ressalta a divulgação deste conhecimento, como uma maneira de resgatar a cultura tradicional do uso de plantas como remédio na Região de Blumenau, Região do Alto Vale Catarinense.

Com os dados obtidos na pesquisa, pode-se afirmar que $78,56 \%$ dos entrevistados não possui nível de escolaridade acima do ensino fundamental, 19,64\% nunca foram à escola. Pode-se dizer que o fato de $82,14 \%$ ser do sexo feminino influi na escolaridade se comparado com a idade dessas mulheres; pois, no caso das mulheres na terceira idade, o motivo é que, na época que eram mais jovens, as condições para as mulheres estudarem eram bem difíceis, devido a morarem longe das escolas ou pelo impedimento imposto pelos pais.

Outro fator que se encaixa nas mulheres mais jovens é que algumas saíram da adolescência e já possuem casa e filhos, desistindo assim da conclusão de seus estudos, outras por já terem desistido e acharem que não dá mais para voltar a estudar. A esse fator escolaridade podemos relacionar ainda a má remuneração mensal; visto que, na maioria das vezes, apenas o homem trabalha e ganha pouco.

\section{Uso de Plantas medicinais}

Do universo pesquisado, $96 \%$ usam plantas medicinais, sendo que $57,14 \%$ cultivam nos seus quintais. Dentre as plantas citadas, predomina-se a utilização de plantas exóticas, totalizando 62 espécies do total de 114 plantas citadas. As plantas nativas citadas são conhecidas principalmente pelas pessoas mais idosas, que já acumularam um conhecimento maior a respeito do assunto. As plantas nativas citadas são oriundas tanto dos quintais quanto do entorno da cidade e das matas.

Segundo Linhares et al. (2014), tanto ambientes naturais quanto modificados pelo homem podem ser explorados para obtenção de plantas medicinais. Na maior parte das zonas rurais brasileiras, quintais e pomares próximos da casa desempenham uma função importante na manutenção de muitas espécies medicinais, sendo que o quintal é o local onde se cultiva as espécies mais utilizadas pela família, desde a nativa da região, até outras espécies exóticas.

Já o conhecimento dos jovens está diretamente relacionado com as plantas cultivadas nos quintais. Tanto as plantas nativas quanto exóticas utilizadas pela população envolvida na pesquisa são coincidentes com as mencionadas em outros trabalhos realizados pelo país, a exemplo de Christo et al. (2010), Gomes et al. (2017), Lima et al. (2012), Zeni et al. (2017), entre outros. Foi indicado pela população um total 97 espécies, utilizadas como medicinal no Bairro estudado. Deste total, conforme a tabela a seguir, das plantas medicinais cultivadas com 51 espécies e com 46 espécies nativas, com seus respectivos usos, preparos e espécie/família sugerida. 
Tabela 2: Relação das espécies Identificadas e citadas como Plantas Medicinais Cultivadas em Santa Isabel.

\begin{tabular}{|c|c|c|c|c|}
\hline Nome vulgar & Nome Científico & Indicação & Parte utilizada & Preparo \\
\hline Abacateiro & Persea americana & Rins, prostatite. & Folha & Chá, infusão \\
\hline Acerola & $\begin{array}{l}\text { Malpighia } \\
\text { emarginata }\end{array}$ & Fraqueza, magreza & Fruto & Suco, xarope \\
\hline Açafrão & Curcuma longa & Expectorante, gripe, resfriado & Raiz & Chá ou amassado \\
\hline Agrião japonês & $\begin{array}{l}\text { Nasturtium } \\
\text { officinale }\end{array}$ & Gripe, tosse resfriado & Folhas & chá, xarope \\
\hline Alecrim & $\begin{array}{l}\text { Rosmarinus } \\
\text { officinalis }\end{array}$ & $\begin{array}{l}\text { Calmante, circulação, problemas } \\
\text { cardíacos }\end{array}$ & Parte aérea da planta & chá, tintura \\
\hline Alfavaca & Ocimum basilicum & $\begin{array}{l}\text { Gripe, tosse, flatulência, saborizante, } \\
\text { condimento }\end{array}$ & Parte aérea da planta & Chá, tintura, xarope \\
\hline Amoreira & Morus sp. & Fígado e para menopausa & Casca e fruto & Fruta in natura \\
\hline Anador & Justicia pectoralis & $\begin{array}{l}\text { Cólicas, dores, analgésico, bronco } \\
\text { dilatador }\end{array}$ & Toda planta & Chás e xaropes \\
\hline Angélica & $\begin{array}{l}\text { Angelica } \\
\text { archangelica }\end{array}$ & Má digestão, abortiva & Casca e raiz & Chá, molho na água \\
\hline Arruda & Ruta graveolens & Dores, cólicas menstruais, inflamações & Toda planta & Emplastos, cataplasma \\
\hline Amica & Arnica montana & $\begin{array}{l}\text { Contusões, hematomas, dores } \\
\text { reumáticas }\end{array}$ & Parte aérea da planta & Sumo, emplasto, cataplasma \\
\hline Artemísia & Artemisia vulgaris & $\begin{array}{l}\text { Estomago, má digestão, moleza, cólicas } \\
\text { menstruais }\end{array}$ & Parte aérea da planta & Chá e infusão \\
\hline Artemijo & $\begin{array}{l}\text { Artemísia } \\
\text { dracunculus }\end{array}$ & Enxaqueca, diarreia, gastrite & Parte aérea da planta & Infusão \\
\hline Babosa & Aloe Vera & Anti-helmíntica, queimaduras e eczemas & Folhas, resina & $\begin{array}{l}\text { Polpa, suco, seiva e } \\
\text { cataplasma }\end{array}$ \\
\hline Beladona & Atropa belladonna & Asma, brônquica, coqueluche & Folhas & Chá \\
\hline Batata Inglesa & Solanum tuberosum & Apetite exagerado, gastrite & Tubércilo & Sumo do tubérculo \\
\hline $\begin{array}{l}\text { Boldo (falso } \\
\text { boldo) }\end{array}$ & $\begin{array}{l}\text { Plectranthus } \\
\text { barbatus }\end{array}$ & Adstringente tônica, sangramento local & Folhas & Chá, sumo \\
\hline Carambola & Averrhoa carambola & Açúcar no sangue, obesidade & Folha e fruto & Chá \\
\hline Carqueja & Baccharis trimera & $\begin{array}{l}\text { Dispepsia, afecções hepáticas, diabetes } \\
\text { melitus }\end{array}$ & Toda planta & Chá \\
\hline $\begin{array}{l}\text { Comigo } \\
\text { ninguém pode }\end{array}$ & $\begin{array}{l}\text { Dieffenbachia } \\
\text { seguine }\end{array}$ & Tóxica, alergizaste, mal olhado, azar & Folha & Banho \\
\hline Coentro & Coriandrum sativum & Aromatizante, condimento, gases & Frutículos & Infusão \\
\hline Chuchu & Coriandrum sativum & $\begin{array}{l}\text { Pressão alta, calmante, ácido úrico, } \\
\text { diurético }\end{array}$ & Fruto, folha (broto) & Salada, Infusão \\
\hline Levante & Mentha viridis & Estomago, gases, gripe, resfriado & Parte aérea da planta & Chá \\
\hline Erva cidreira & Melissa officinalis & Antiespasmódico, calmante, digestivo & Folhas & Chá, Infusão \\
\hline Erva de Santa & $\begin{array}{l}\text { Chenopodium } \\
\text { ambrisioides }\end{array}$ & Diurética, vermífuga, angina & Parte aérea da planta & $\begin{array}{l}\text { Infusão, sumo, cataplasma, } \\
\text { xarope }\end{array}$ \\
\hline Erva Doce & Pimpinella anisum & Antiespasmódico, calmante, digestivo & Frutículos & Chá, mistura no leite, xarope \\
\hline Espinheira Santa & Maytenus ilicifolia & $\begin{array}{l}\text { Ressaca alcoólica, antiasmática, feridas, } \\
\text { úlceras }\end{array}$ & Folhas & Chá, tintura \\
\hline Fedegoso & Senna macranthera & Laxante & $\begin{array}{l}\text { Folhas, Raiz, brotos, } \\
\text { sumo }\end{array}$ & Chá, tintura \\
\hline Goiabeira & Psidium guajava & $\begin{array}{l}\text { Anti-infeccioso intestinal, antidiarreico, } \\
\text { garganta }\end{array}$ & Folha & Chá \\
\hline Gengibre & Zingiber officinale & $\begin{array}{l}\text { Estimulante, gastrintestinal, flatulência, } \\
\text { rouquidão }\end{array}$ & Raiz & Chá, cataplasma, xarope \\
\hline Guiné & Petiveria alliacea & $\begin{array}{l}\text { Dor de dente, enxaqueca, tóxica, picada } \\
\text { de cobra }\end{array}$ & Raiz & $\begin{array}{l}\text { Chá, molho no álcool, } \\
\text { compresso }\end{array}$ \\
\hline Guaco & Mikania glomerata & $\begin{array}{l}\text { Bronco dilatador, expectorante, séptico } \\
\text { respiratório }\end{array}$ & Folhas & Infusão, xarope \\
\hline Hortelã & Mentha $\times$ piperita & $\begin{array}{l}\text { Carminatica, aromatizante, flatulência, } \\
\text { gripe }\end{array}$ & Folhas & Chá, melado, xarope \\
\hline Hortelã Rasteira & $\begin{array}{l}\text { Mentha X villosa } \\
\text { Huds }\end{array}$ & $\begin{array}{l}\text { Giardicida, tricomonicida, diarreia } \\
\text { sanguinolenta }\end{array}$ & Folhas & Chá, melado, xarope \\
\hline Hortelã Vique & $\begin{array}{l}\text { Mentha arvensis } L \text {. } \\
\text { var }\end{array}$ & $\begin{array}{l}\text { Estômago, expectorante, } \\
\text { descongestionante }\end{array}$ & Folhas & Chá, melado, xarope \\
\hline Laranjeira & Citrus $X$ sinensis & Tosse, gripe, diarreia, insônia & Folha, fruto, semente & $\begin{array}{l}\text { Semente torrada, Chá, } \\
\text { melado }\end{array}$ \\
\hline Limão & Citrus limonum & Gripe, resfriado, depurativo & Frutos & Chá, suco \\
\hline Losna & $\begin{array}{l}\text { Artemisia } \\
\text { absinthium }\end{array}$ & Estomáquica, falta de regras, abortivas & Toda parte aérea & Chá, banho \\
\hline Mamoeiro & Carica papaya & Vermífuga, proteolítico, estomáquico & Folha e flor & $\begin{array}{l}\text { Chá, semente, melado (sem } \\
\text { raiz) }\end{array}$ \\
\hline Mangueira & Mangifera indica & Alimento, tosse, gripe, resfriado & Fruto, folhas, casca & Chá, suco, xarope \\
\hline Macela & $\begin{array}{l}\text { Achyrocline } \\
\text { satureioides }\end{array}$ & $\begin{array}{l}\text { Analgésico, estomáquico, antidiarreico, } \\
\text { enxaqueca }\end{array}$ & Toda parte aérea & Chá \\
\hline Cavalinha & Equisetum arvense & $\begin{array}{l}\text { adstringente, anti-inflamatória, diurética } \\
\text { e desintoxicante }\end{array}$ & Folhas & Chá \\
\hline
\end{tabular}




\begin{tabular}{|c|c|c|c|c|}
\hline Nos moscada & Myristica fragrans & Flatulência, astenia, dispepsia, abortiva & Semente & Chá \\
\hline Poejo & Mentha pulegium & Antisséptico, tosse, gripe, expectorante & Folhas, talos, flores & Chá \\
\hline Quebra Pedra & Phyllanthus niruri & $\begin{array}{l}\text { Diurético, cistite, hipertensão, pedra nos } \\
\text { rins }\end{array}$ & Toda a planta & Chá \\
\hline Rosa branca & Rosa $\times a l b a$ & $\begin{array}{l}\text { Colírio, blenorragia, laringites, } \\
\text { ulcerações }\end{array}$ & Flores & $\begin{array}{l}\text { Gargarejo, banhos, colírio, } \\
\text { chá }\end{array}$ \\
\hline Romã & Punica granatum & Adstringente, antiviral, antimicrobiano & Fruto, semente, casca & Chá, melado \\
\hline Salsinha & $\begin{array}{l}\text { Petroselinum } \\
\text { crispum }\end{array}$ & $\begin{array}{l}\text { Flatulência, diurética, febrífuga, } \\
\text { parasitoses }\end{array}$ & Toda parte aérea & Chá \\
\hline Tanchagem & Plantago major & $\begin{array}{l}\text { Expectorante, cicatrizes, adstringente, } \\
\text { emoliente }\end{array}$ & Toda a planta & $\begin{array}{l}\text { Infusão, cataplasma, } \\
\text { gargarejo }\end{array}$ \\
\hline Terramicina & $\begin{array}{l}\text { Alternanthera } \\
\text { brasiliana }\end{array}$ & $\begin{array}{l}\text { Febre, anti-inflamatório, adstringente, } \\
\text { antisséptica }\end{array}$ & Parte aérea da planta & Chá, lavagem \\
\hline Urucum & Bixa orellana & $\begin{array}{l}\text { Vitamínico, expectorante, bronco } \\
\text { dilatador }\end{array}$ & Raiz, sementes, folhas & Infusão, xarope \\
\hline Alcaçuz & Glycyrrhiza glabra & Coração, diurético, expectorante & Raiz & Infusão, decoração \\
\hline Algodão grande & $\begin{array}{l}\text { Gossypium } \\
\text { barbadense }\end{array}$ & $\begin{array}{l}\text { Menopausa, inflamação do ovário, } \\
\text { diurético }\end{array}$ & Raiz e folhas & Infusão \\
\hline Aldodãozinho & $\begin{array}{l}\text { Cochlospermum } \\
\text { regium }\end{array}$ & $\begin{array}{l}\text { Depurativo, ulcerações, gastrite, } \\
\text { infecções }\end{array}$ & Raiz & Garrafa, infusão, xarope \\
\hline Angico & $\begin{array}{l}\text { Anadenanthera } \\
\text { macrocarpa }\end{array}$ & $\begin{array}{l}\text { Brônquico, anemia, sangramentos, } \\
\text { expectorante }\end{array}$ & Casca, gomo, resina & $\begin{array}{l}\text { Chá, xarope, melado, } \\
\text { gargarejo }\end{array}$ \\
\hline Aroeira & $\begin{array}{l}\text { Schinus } \\
\text { terebinthifolius }\end{array}$ & $\begin{array}{l}\text { Anti-inflamatório, antialérgico, } \\
\text { antirreumático }\end{array}$ & Casca & $\begin{array}{l}\text { Infusão, gargarejo, xarope, } \\
\text { banhos }\end{array}$ \\
\hline Assa-Peixe & $\begin{array}{l}\text { Vernonia } \\
\text { polysphaera }\end{array}$ & Tosse crônica, gripe, bronquite & Folha & Xarope, infusão \\
\hline Barbatimão & $\begin{array}{l}\text { Stryphnodendron } \\
\text { adstringens }\end{array}$ & $\begin{array}{l}\text { Inflamação do útero, ovário, vagina, } \\
\text { cortes }\end{array}$ & Ante caule e casca & Banho, infusão, garrafada \\
\hline $\begin{array}{l}\text { Batata de Purga } \\
\text { Branca }\end{array}$ & Ipomoea purga & Depurativo, impetigo, laxante, gripe & Tubérculo & Chá, xarope, melado \\
\hline Cana Brava & $\begin{array}{l}\text { Gynerium } \\
\text { sagittatum }\end{array}$ & Dor de barriga, diarreia, feridas, sífilis & Folhas e raiz & $\begin{array}{l}\text { Chá, lavagem, tintura, } \\
\text { infusão }\end{array}$ \\
\hline Cana de Macaco & Costus spicatus & $\begin{array}{l}\text { Problemas renais, bexiga, uretra, } \\
\text { cálculos renais }\end{array}$ & Parte aérea & $\begin{array}{l}\text { Infusão, sumo, cataplasma, } \\
\text { lavagem }\end{array}$ \\
\hline Carobinha & Jacaranda decurrens & $\begin{array}{l}\text { Depurativo, pressão alta, giardíase, } \\
\text { feridas, coceiras }\end{array}$ & Raiz, casca, folhas & $\begin{array}{l}\text { Garrafada, tintura, banho, } \\
\text { óleo, pomada }\end{array}$ \\
\hline Cáscara Sagrada & Rhamnus purshiana & Constipação intestinal & Caule (casca) & Casca ralada \\
\hline $\begin{array}{l}\text { Chapéu de } \\
\text { Couro }\end{array}$ & $\begin{array}{l}\text { Echinodorus } \\
\text { grandiflorus }\end{array}$ & $\begin{array}{l}\text { Rins, reumatismo, pele, artrites, cistites, } \\
\text { estômago }\end{array}$ & Folhas & Infusão, garrafada \\
\hline $\begin{array}{l}\text { Cipó Tripa de } \\
\text { Galinha }\end{array}$ & $\begin{array}{l}\text { Dalechampia } \\
\text { Tiliaefolia }\end{array}$ & $\begin{array}{l}\text { Colesterol, ácido úrico, diarreia, dor de } \\
\text { barriga }\end{array}$ & Raiz & Banho, maceração em água \\
\hline Copaíba & $\begin{array}{l}\text { Copaifera } \\
\text { langsdorffii }\end{array}$ & $\begin{array}{l}\text { Sinusite, câncer, doenças venéreas, } \\
\text { úlceras, feridas }\end{array}$ & $\begin{array}{l}\text { Caule (centro da } \\
\text { madeira), seiva }\end{array}$ & $\begin{array}{l}\text { Óleo, vinho, xarope, } \\
\text { maceração, pomada }\end{array}$ \\
\hline Cruzadinha & Cynara scolymus & Cicatrizante, torsões & Folhas & Emplastro \\
\hline Cordão de Frade & Leonotis nepetifolia & $\begin{array}{l}\text { Digestivo, diurético, asma, cicatrizante, } \\
\text { fortificante }\end{array}$ & Toda a planta & Xarope, infusão, banho \\
\hline Desinchadeira & $\begin{array}{l}\text { Eupatorium } \\
\text { maximilianni }\end{array}$ & Inchaço do corpo & Toda a planta & Chá, banho \\
\hline Erva de Bugre & Casearia Sylvestris & $\begin{array}{l}\text { Depurativo, antirreumático, cicatrizante, } \\
\text { calmante }\end{array}$ & Folhas & Chá, emplastro \\
\hline Erva Santa Luzia & Commelina erecta & $\begin{array}{l}\text { Úlceras, feridas velhas, inflamações das } \\
\text { pálpebras }\end{array}$ & Folhas & Chá, cataplasma, lavagem \\
\hline $\begin{array}{l}\text { Espinho de } \\
\text { Carneiro }\end{array}$ & $\begin{array}{l}\text { Acanthospermum } \\
\text { hispidum }\end{array}$ & $\begin{array}{l}\text { Bronco dilatador, expectorante, gripe, } \\
\text { asma }\end{array}$ & toda a planta & $\begin{array}{l}\text { Cataplasma, emplastro, } \\
\text { lavagem }\end{array}$ \\
\hline Imburana & $\begin{array}{l}\text { Commiphora } \\
\text { leptophloeos }\end{array}$ & Cólicas menstruais, prisão de ventre & Toda a planta & Xarope, chá \\
\hline Ipê roxo & $\begin{array}{l}\text { Handroanthus } \\
\text { impetiginosus }\end{array}$ & $\begin{array}{l}\text { Artrite, asma, tosse seca, infecção do } \\
\text { ovário e útero }\end{array}$ & $\begin{array}{l}\text { Toda a planta, } \\
\text { semente, resina }\end{array}$ & Chá \\
\hline Jatobá & Hymenaea courbaril & $\begin{array}{l}\text { Tosse, bronquite, diarreia, cólica, } \\
\text { fortificante }\end{array}$ & Caule e casca & $\begin{array}{l}\text { Lavagem, infusão, garrafada, } \\
\text { xarope }\end{array}$ \\
\hline Jarrinha & $\begin{array}{l}\text { Aristolochia cymbifer } \\
a\end{array}$ & $\begin{array}{l}\text { Febrífuga, bronquite, menstruação } \\
\text { irregular }\end{array}$ & $\begin{array}{l}\text { Caule (casca), fruto } \\
\text { (polpa) seiva }\end{array}$ & $\begin{array}{l}\text { Xarope infusão, decocção, } \\
\text { garrafada }\end{array}$ \\
\hline Jurubeba & $\begin{array}{l}\text { Solanum } \\
\text { paniculatum }\end{array}$ & $\begin{array}{l}\text { Feridas, diurético, tônico, baço, bexiga, } \\
\text { fígado }\end{array}$ & Raiz e cipó & Chá \\
\hline Lírio São José & Hemerocallis flava & Purgativa, afecções pulmonares & Raiz, folhas, fruto & Infusão \\
\hline Mandacaru & Cereus jamacaru & $\begin{array}{l}\text { Gripe, asma, catarro, gota, verrugas, } \\
\text { abcessos }\end{array}$ & Rizoma & Decocção \\
\hline Marroio & Marrubium vulgare & $\begin{array}{l}\text { Desobstruente do fígado e baço, dores } \\
\text { do corpo }\end{array}$ & Caule (sumo), raiz & $\begin{array}{l}\text { Xarope, infusão, banho, } \\
\text { cataplasma }\end{array}$ \\
\hline Mentrasto & $\begin{array}{l}\text { Ageratum } \\
\text { conyzoides }\end{array}$ & $\begin{array}{l}\text { Cólicas, menstruação, tônico, febrífugo, } \\
\text { depressão }\end{array}$ & Folhas, sementes & Decocção, banho \\
\hline Nó de Cachorro & $\begin{array}{l}\text { Heteropterys } \\
\text { afrodisíaca }\end{array}$ & $\begin{array}{l}\text { Impotência sexual, sistema nervosos, } \\
\text { tônico }\end{array}$ & Planta & Infusão, tintura, chá \\
\hline Palma & Opuntia ficus-indica & Puxar espinho, feridas, bronquite & Raiz & Infusão, garrafada (cachaça) \\
\hline
\end{tabular}




\begin{tabular}{|c|c|c|c|c|}
\hline Perpetua roxa & Gomphrena globosa & $\begin{array}{l}\text { Problema respiratório, febre, tosse, } \\
\text { coração }\end{array}$ & Caule & $\begin{array}{l}\text { Emplastro, cataplasma, } \\
\text { melado }\end{array}$ \\
\hline Picão & Bidens sulphurea & $\begin{array}{l}\text { Hepatite, icterícia, diabetes, vermífugo, } \\
\text { digestivo }\end{array}$ & Semente, folha, raiz & $\begin{array}{l}\text { Infusão, garrafada, banho, } \\
\text { gargarejo }\end{array}$ \\
\hline Pequi & Caryocar brasiliense & Ferimentos, problemas urinários, gripe & Folhas e frutos & Óleo, xarope \\
\hline Ponta Lívia & Achillea millefolium & Para todo tipo de dor & Folhas & Chá \\
\hline Poaia & $\begin{array}{l}\text { Carapichea } \\
\text { ipecacuanha }\end{array}$ & Sarampo, coqueluche, desinteria & Raiz & Chá \\
\hline Quina & Cinchona officinalis & $\begin{array}{l}\text { Vermífugo, estimulante do apetite, } \\
\text { anemia }\end{array}$ & Caule (casca) & Molho na água, Infusão \\
\hline Rubim & Leonurus sibiricus & $\begin{array}{l}\text { Infecção intestinal, febre, colesterol, } \\
\text { hemorroidas }\end{array}$ & Folhas & Infusão \\
\hline Salsa Paredão & $\begin{array}{l}\text { Petroselinum } \\
\text { crispum }\end{array}$ & Reumatismo, depurativo do sangue & Raiz & Xarope, chá, banho \\
\hline Salsa Parrilha & Smilax ornata & Reumatismo, depurativo do sangue & Raiz & Chá, xarope, banho \\
\hline Sapé & Imperata brasiliensis & Emoliente, diurético, sudorífica & Raiz & Infusão, melado \\
\hline Sabugueiro & Sambucus nigra & Febre, tosse & Folhas & Chá \\
\hline Sucupira & $\begin{array}{l}\text { Pterodon } \\
\text { emarginatus }\end{array}$ & $\begin{array}{l}\text { Depurativo do sangue, elefantíase, sífilis, } \\
\text { gota }\end{array}$ & Semente e caule & $\begin{array}{l}\text { Infusão, garrafada, melado, } \\
\text { banho }\end{array}$ \\
\hline Vassourinha & Scoparia dulcis & Constipação, diurético, piolhos, febre & Planta inteira & Infusão, banho, compressa \\
\hline Velame & $\begin{array}{l}\text { Croton } \\
\text { heliotropiifolius }\end{array}$ & Depurativo do sangue, pele, feridas & Raiz & $\begin{array}{l}\text { Banho (raiz em pó), infusão, } \\
\text { garrafada }\end{array}$ \\
\hline
\end{tabular}

A figura 2 apresenta 62 espécies cultivadas representando um percentual de $52,5 \%$ e as nativas 47,5\%. A parte das plantas mais utilizada foi a folha (parte aérea) representada por $52 \%$ das respostas, seguida de $19 \%$ cascas e $12 \%$ raízes, como apresentado na Figura 3, logo abaixo, esse resultado pode significar um grande risco na manutenção das espécies, uma vez que a coleta de cascas e raízes correspondem em $27 \%$ das respostas obtidas.

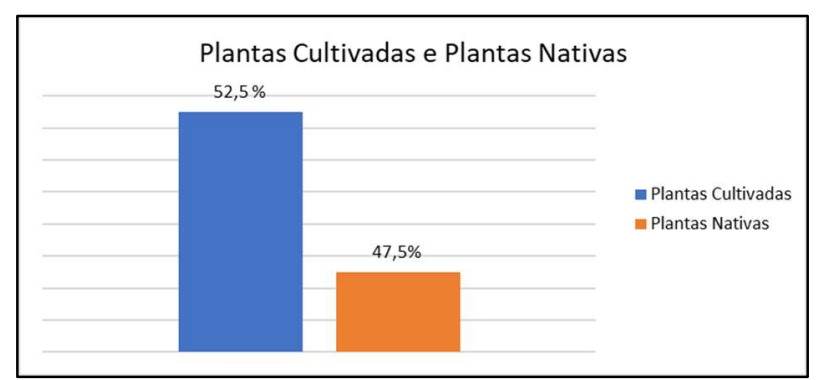

Figura 2: Relação entre as ervas cultivadas e as nativas.

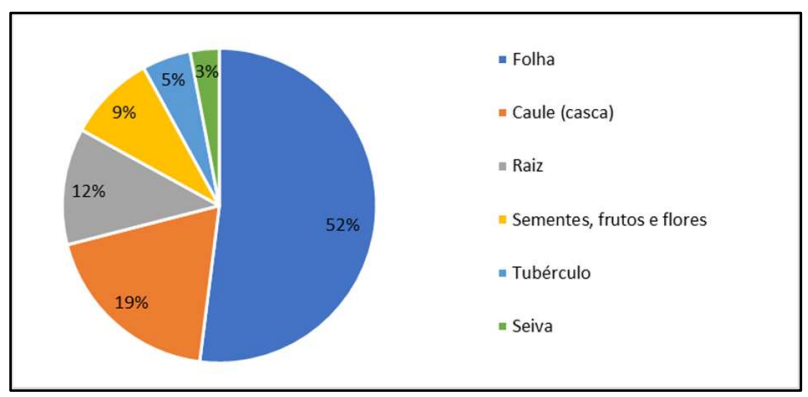

Figura 3: Distribuição percentual por partes das plantas utilizadas.

Quanto à indicação de plantas medicinais, a diversidade de usos dessas plantas pela população é bem diversificados. Geralmente as pessoas tendem a conhecer as plantas que eles mais necessitam, visto que $23 \%$ das pessoas responderam que possuem problemas renais e estavam cansados de remédios químicos, passando a conhecer e usar as plantas. As indicações mais comuns são: dores, cólicas, problemas menstruais, diarreias, gripes, resfriados, problemas estomacais, reumatismos. Conforme a indicação, registra-se o tipo de preparo dessas plantas. Geralmente plantas indicadas como expectorante, são preparadas como melado ou xarope.

Tem-se ainda várias formas de preparo, por exemplo, a casca da Aroeira-preta (Myracrodruom urundeuva) é utilizada nos tratamentos de infecções na forma de chá, tanto para gargarejo quanto para lavagem das partes íntimas. Dentre os preparos mais citados na pesquisa, destacam-se: gargarejos, emplastos, cataplasmas, tintura, chá, infusão, xaropes, melados, suco, fruta in natura, supositório, compressas, banhos, sumo. Muitas pessoas entrevistadas cultivam as plantas caseiras para problemas 
comuns como cólicas, gripes, dores, inflamação de garganta, problemas femininos. Acreditam e recorrem aos seus quintais para aliviarem ou sanarem seus males.

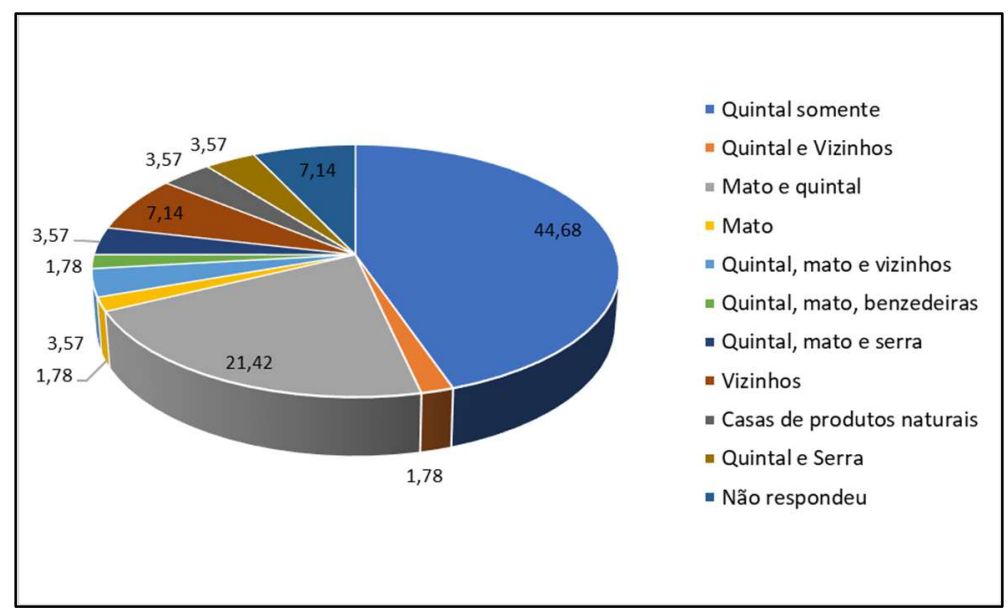

Figura 4: Percentual dos locais nos quais as plantas são cultivadas e extraídas.

Na pesquisa feita com a população do bairro, considerando a figura 4 abaixo, observou-se que no total $53,60 \%^{1}$ das pessoas entrevistadas, ou possuem as ervas nos quintais, ou tem o costume de pegá-las nos quintais vizinhos ou de parentes. No entorno do bairro, é encontrada pouca vegetação espontânea, devido ao desmate, as queimadas e a grande quantidade de pastagem; contudo, o número de pessoas que obtém de alguma forma no mato perfaz um total de $32,12 \%^{2}$, isso significa perante a realidade do bairro que essas pessoas vão longe buscar ou encomendar essas plantas a parentes moradores da zona rural do município. Têm-se ainda pessoas que acham ser mais prático comprar em farmácia natural. Assim alguns preferem usar remédios naturais sem nenhum esforço de cultivá-los ou prepará-los.

Segundo Christo et al. (2010), o alto valor de plantas obtidas em quintais tem procedência cultural e que nem sem sempre o manejo da flora constituem processos de domesticação como a agricultura. Exemplo disso são os Astecas do México, que ao manipularem a vegetação local, criaram zonas antropizadas de vegetação que se iniciavam ao redor das casas, nos quintais e se estendiam até a floresta, sendo que ao redor de suas casas eles cultivavam plantas medicinais que com o tempo, o número de plantas úteis ia aumentando.

Pode-se constatar que se tem duas vertentes, onde muitos gostam de cultivar suas plantas de uso diário em seus quintais e outros que acham difícil cultivar preferem pegar em vizinhos, comprar em farmácias naturais ou raizeiros de outras cidades. Têm-se ainda pessoas que não responderam e aquelas que acham melhor usar remédios químicos porque o efeito é mais rápido. Já outras pessoas têm verdadeiro gosto em cultivar ou ir buscar essas plantas, uma vez que esse tipo de remédio se toma mais barato e mais saudável. Zeni et al. (2017), também observou esse caráter cultivador da população pesquisada, esse dado aqui também foi constatado, quando na figura acima é amostrado o número de pessoas que possuem plantas medicinais em seus quintais.

\footnotetext{
${ }^{1}$ Quintal somente $44,68+$ quintal e vizinhos $1,78+$ vizinhos7, $14=53,60 \%$

2 Mato e quintal 21,42 + mato 1,78 + Quintal, mato e vizinhos 3,57 + Quintal, mato e benzedeiras 1,78 + quintal, mato e serra 3,57 = 32,12. 
Há pessoas que responderam que é fácil adquirir essas plantas, outros foram mais cautelosos, disseram que as cultivadas são fáceis, contudo, as nativas são difíceis, muitas vezes tem que buscar em lugares mais longes, áreas que sofrem menos a ação do homem. Antônio et al. (2014), registra a facilidade do cultivo de plantas nos quintais, o que é observado também nessa pesquisa, esse fenômeno se dá pelo desmatamento de áreas em que antes eram mata, deram lugar hoje a grandes pastagens para pecuária extensiva, havendo a troca de vegetação nativa pela cultivada, alterando grandes áreas e provocando a eliminação das plantas em seu ambiente natural.

As respostas demonstram as claras as relações de aprendizagem de uso de plantas medicinais, possibilitando conceituar padrões de pessoas que estão mais particularmente ligadas a cultura tradicional, principalmente quando é mencionado o aprendizado através de pessoas mais velhas, essas pessoas são geralmente ligadas ao indivíduo entrevistado, seus pais, avós, pessoas de um convívio bem próximo.

A interdisciplinaridade do estudo etnoecológico abrange a análise e a interpretação do conhecimento, valor cultural, manejo e usos tradicionais dos elementos naturais. Sendo assim, pode-se dizer que ocorre algumas variantes por exemplo idade, para se levar em consideração para o nível de conhecimento que a pessoa tem a respeito do assunto plantas medicinais, onde as pessoas mais idosas são na verdade as grandes acumuladoras desses conhecimentos ao longo dos anos, contudo a pesquisa mostra que há um elevado número de pessoas no intervalo de 15 a 40 anos, conhecedoras desse conhecimento que a eles foram repassados na maioria das vezes pelos pais ou avós. Pode-se então observar que o número de plantas citadas pelos entrevistados na faixa de 15 até 40 anos é menor, totalizando 94 plantas e já as citadas pelos entrevistados de 40 até 80 é de 154 plantas citadas nas entrevistas.

Tal grupo é caracterizado por Faria (1998), por pessoas do sexo feminino, com mais de 50 anos, sem estudo ou com ensino fundamental incompleto que aprenderam suas receitas, com pessoas antigas, parentes próximos (pais, avós) e até mesmos pela experiência de vida adquirida ao longo dos anos. Constatou-se que, no bairro de Santa Isabel, a cultura das plantas medicinais está renascendo entre os mais jovens, ou seja, está sendo repassada pelos mais velhos aos mais jovens.

Conforme Gomes et al. (2017), as relações etnoecológicas são aquelas onde ocorre o envolvimento humano na utilização dos recursos naturais com as relações entre si e com o meio ambiente. A herança cultural é a grande responsável por esse acumulo de informações que ocorre, através das pessoas mais velhas. Essa herança nos dias de hoje está se tomando de grande valia, pois, está ocorrendo uma crescente busca pelo natural, descartando os recursos geneticamente modificados e toda a tecnologia empregada na obtenção de alimentos mais vistosos.

Muitas vezes o fato de não se ter dinheiro ou localidade distantes dos recursos mais modernos da saúde, faz com que o homem busque mecanismos de sobrevivência mais condizentes com sua própria realidade. Segundo Matos et al. (1999), dessa mesma forma, manifesta-se à importância do uso de plantas medicinais abordando a fitoterapia sob o ponto de vista econômico, perpetuando assim o saber popular como uma alternativa real para a população mais necessitada economicamente.

Segundo o referido autor, raizeiros 'são especialistas em plantas medicinais de uso popular'. 
Trabalham no meio urbano, comercializam raízes, cascas e folhas de plantas medicinais, ou produtos tipo 'garrafadas', que geralmente são preparados por eles, além disso, consultam e diagnosticam a pessoas prescrevendo dieta alimentar e as plantas a serem usadas conforme o quadro apresentado a ele.

Apenas em Santa Isabel foi encontrado apenas um casal idoso que atende ao conceito de raizeiro descrito acima, exceto no fato da comercialização e da consulta. A entrevista foi realizada em conjunto com o casal; ambos apresentam respectivamente 57 e 55 anos, sendo seu M. originário de Ipanema/MG e dona S. de Maringá/PR, moradores há aproximadamente 15 anos. Além de raizeiros, o casal pode ser considerado como benzedores conforme o conceito apresentado por Zeni et al. (2017), uma pessoa que se limita a rezar sobre a pessoa enferma, não receita remédios, reza fazendo o sinal da cruz, não precisa a presença do doente para que possa realizar as orações para o doente.

O casal relata que na maioria das vezes são mais procurados por mulheres sem distinção de classe social, sendo ainda procurados pelos vizinhos, amigos, conhecidos, e também por estranhos que muitas vezes já se cansaram de procurar outros meios para amenizar seus problemas. A familiarização dos raizeiros ou pessoas que tradicionalmente conhecem muito sobre plantas medicinais inicia-se muito cedo na maioria dos casos, aprendem com parentes muito próximos (pais, avós).

Esta medicina tradicional realizada por pessoas denominados raizeiros geralmente podem ser considerados limitativa pela medicina padrão; contudo, deve-se respeitar o uso de ervas como uma ciência, muitas vezes, relacionada com a observação da natureza e do comportamento dos animais, contribui muito para a construção do conhecimento do uso de algumas plantas medicinais.

O processo de formação da cultura do uso de plantas como remédio, é muito importante diante do contraste entre o vulgar e o científico, a medicina oficial e a popular, através de estudos científicos comprovam que muitas práticas populares e tradicionais anteriormente consideradas absurdas são explicadas e aplicadas mais constantemente. No município, muitos médicos já estão acompanhando essa consciência e muitos receitam remédios fitoterápicos, manipulados em farmácias naturais.

Portanto, observa-se que o conhecimento da medicina oficial não pode ser colocado como absoluto e nem continuar acreditando que as crenças populares como sendo irracionais, tem-se uma grande riqueza no conhecimento tradicional e que os ensinamentos tiveram grande influência dos ensinamentos médicos do passado. De acordo com Neto et al. (2014), os trabalhos etnobotânicos devem identificar, descrever e classificar os organismos estudados, buscar o conhecimento da sua distribuição e as relações ecológicas, valorizando estes para a comunidade e os modos de utilização, descrevendo a influência histórica do conhecimento herdado através de gerações a respeito dos usos, indicações que as plantas possuem.

\section{CONCLUSÕES}

A sociedade humana acumula informações sobre o ambiente acerca das formas de interagir com ele, para melhorar as necessidades de sobrevivência, dando assim origem a uma categoria de conhecimento classificada como popular. Diante do estudo envolvendo a população do Bairro de Santa Isabel/SC, encontramos pessoas ativamente praticantes da medicina popular, mostrando que a prática dessa cultura 
pelo púbico alvo da pesquisa é bastante aceita e progressista para as gerações futuras, contrariando aquilo que o senso comum indicava; visto que, de modo geral, responde positivamente ao questionamento da pesquisa no que tange ao bem estar da população local diante de uma suposta falta de valorização dos conhecimentos sobre plantas medicinais.

Pode-se ressaltar que o aspecto pluridimensional da pesquisa, mediante a realidade de grande parte dos entrevistados ser originária de outros estados, com graus de instrução variando de indivíduos que nunca foram à escola até cursando o ensino superior; sendo que, em sua maioria, não completaram o Ensino Fundamental, característica associada a diversos locais no Brasil.

A maior parte dos entrevistados relatam que cultivam as plantas que usam em seus quintais, e que é muito mais fácil pegá-las no quintal que em outros lugares tipo: serra, mato, raizeiro. Infelizmente a prática da medicina natural se realiza só pela crença ou pela tradição, muitas vezes e na maioria dos casos é pela falta ou deficiência de um Sistema de Saúde pública eficiente que atenda satisfatoriamente a população rural ou carente.

Sendo assim, pode-se observar a população alvo, ao utilizar recursos vegetais, estabeleceu uma relação etnobotânica com o meio ambiente em que vivem, além de uma profunda interação social com seus vizinhos; identificando, experimentando, trocando e elaborando conceitos próprios; sendo estes repassados aos outros por meio dessa cultura milenar do cultivo e do uso de plantas medicinais, perfazendo-se, assim, de suma importância o respeito por essa cultura popular tão fascinante e intrigante.

\section{REFERÊNCIAS}

ANTÔNIO, G. D.; TESSER, C. D.; MORETTI-PIRES, R. O.. Phytotherapy in primary health care. Rev. Saúde Pública, v.48, n.3, p.541-553, 2014. DOI: https://doi.org/10.1590/S0102-311X2007000600021

CHRISTO, A. G.; GUEDES-BRUNII, R. R.; SILVA, A. G.. Local knowledge on medicinal plant gardens in a rural community near the Atlantic Rain Forest, southeastern Brazil. Rev. Brás Farmacogn., v.20, n.4, p.494-501, 2010. DOI: http://dx.doi.org/10.1590/S0102-695X2010000400006

GOMES, T. M.; LOPES, J. B.; BARROS, R. F. M.; ALENCAR, N. L.. Plantas de uso terapêutico na comunidade rural Bezerro morto, São João da Canabrava, Piauí, Brasil. Gaia Scien., v.11, n.1, p.253-268, 2017. DOI:

http://dx.doi.org/10.21707/gs.v11.n01a17

LIMA, R. A.; MAGALHÃES, S. A.; SANTOS, M. R. A.. Levantamento etnobotânico de plantas medicinais utilizadas na cidade de Vilhena, Rondônia. Rev. Pesq. Criação, v.10, n. 2, 2011.

LINHARES, J. F. P.; HORTEGAL, E. V.; RODRIGUES, M. I. A.; SILVA, P. S. S.. Etnobotânica das principais plantas medicinais comercializadas em feiras e mercados de São Luís, Estado do Maranhão, Brasil. Rev. Pan Amaz Saúde, v.5, n.3, 2014. DOI: http://dx.doi.org/10.5123/S2176-62232014000300005

MATOS, F. J. A.; MACHADO, M. I. L.; CRAVEIRO, A. A.; ALENCAR, J. W.; SILVA, M. G. V.. Medicinal plants of northeast Brazil containing thymol and carvacrol - Lippia sidoides Cham. and L. gracillis H.B.K. (Verbenaceae). J. Ess. Oil. Res., v.11, n.6, p.666-668, 1999. DOI: https://doi.org/10.1080/10412905.1999.9711990

NETO, F. R. G.; ALMEIDA, G. S. S. A.; JESUS, N. G.; FONSECA, M. R.. Estudo Etnobotânico de plantas medicinais utilizadas pela Comunidade do Sisal no município de Catu, Bahia, Brasil. Rev. Bras. PI. Med., v.16, n.4, p.856-865, 2014. DOI: http://dx.doi.org/10.1590/1983-084X/11 207

OLIVEIRA, M. J. R.; SIMÕES, M. J. S., SASSI, C. R. R.. Fitoterapia no sistema de saúde pública (SUS) no Estado de São Paulo, Brasil. Rev. Bras. PI. Med. v.8, n.2, p.39-41, 2006.

OLIVEIRA, S. G. D.; MOURA, F. R. R.; DEMARCO, F. F.; NASCENTE, O. S.; PINO, F. A. B.; LUND, R. G.. An ethnomedicinal survey on phytotherapy with professionals and patients from Basic Care Units in the Brazilian Unified Health System. J. Ethnopharmacol, v.140, n.2, p.428-437, 2012. DOI: http://dx.doi.org/10.1016/j.jep.2012.01.054

RIBEIRO, L. H. L.. Território e macrossistema de saúde: os programas de fitoterapia no Sistema Único de Saúde (SUS). Tese (Doutorado em Geografia) - Universidade Estadual de Campinas, Campinas, 2015.

SANTOS A. K.. Contribuição ao conhecimento químico de plantas do Nordeste do Brasil: Lippia Sidoides (Cham.) e Mimatanthus drasticus (Mart). Dissertação (Mestrado em Química Orgânica) - Universidade Federal do Ceará, Fortaleza, 2004. 
SILVA, F. S.; RAMOS, M. A.; HANAZAKI, N.; ALBUQUERQUE, U. P.. Dynamics of traditional knowledge of medicinal plants in a rural community in the Brazilian semi-arid region. Rev. Bras. Farmacogn., v.21, n.3, p.382-91, 2011. DOI: http://dx.doi.org/10.1590/S0102-695X2011005000054

TOMAZZONI, M. I.. Subsídios para a introdução do uso de fitoterápicos na rede básica de saúde do município de Cascavel/PR. Dissertação (Mestrado em Enfermagem) Universidade Federal do Paraná, Curitiba, 2014.

TOMAZZONI, M. I.; NEGRELLE, R. R. B.; CENTA, M. L..
Fitoterapia popular: a busca instrumental enquanto prática terapêutica. Rev. Text \& Contex Enferm., v.15, n.1, p.115121, 2006. DOI: http://dx.doi.org/10.1590/S010407072006000100014

TORRES, K. R.. Política Nacional de Plantas Medicinais e Fitoterápicos. In: ENFARMED, 3. Anais. São Paulo, 2009.

ZENI, A. L. B.; PARISOTTO, A. V.; MATTOS, G.; HELENA, E. T. S.. Utilização de plantas medicinais como remédio caseiro na Atenção Primária em Blumenau, Santa Catarina, Brasil. Rev. de Ciênc. \& Saúde Colet., v.22, n.8, p.2703-2712, 2017. DOI: http://dx.doi.org/10.1590/1413-81232017228.18892015

A CBPC - Companhia Brasileira de Produção Científica (CNPJ: 11.221.422/0001-03) detém os direitos materiais desta publicação. Os direitos referem-se à publicação do trabalho em qualquer parte do mundo, incluindo os direitos às renovaç̃ões, expansões e disseminações da contribuição, bem como outros direitos subsidiários. Todos os trabalhos publicados eletronicamente poderão posteriormente ser publicados em coletâneas impressas sob coordenação da Sustenere Publishing, da Companhia Brasileira de Produção Científica e seus parceiros autorizados. Os (as) autores (as) preservam os direitos autorais, mas não têm permissão para a publicação da contribuição em outro meio, impresso ou digital, em português ou em tradução. 